\title{
OPEN Nitrogen addition decreases methane uptake caused by methanotroph and methanogen imbalances in a Moso bamboo forest
}

\author{
Quan $\mathrm{Li}^{1,2}$, Changhui Peng ${ }^{1,3 \bowtie}$, Junbo Zhang ${ }^{2}$, Yongfu $\mathrm{Li}^{2}$ \& Xinzhang Song ${ }^{2 \bowtie}$
}

Forest soils play an important role in controlling global warming by reducing atmospheric methane $\left(\mathrm{CH}_{4}\right)$ concentrations. However, little attention has been paid to how nitrogen $(\mathrm{N})$ deposition may alter microorganism communities that are related to the $\mathrm{CH}_{4}$ cycle or $\mathrm{CH}_{4}$ oxidation in subtropical forest soils. We investigated the effects of $\mathrm{N}$ addition $\left(0,30,60\right.$, or $\left.90 \mathrm{~kg} \mathrm{~N} \mathrm{ha}^{-1} \mathrm{yr}^{-1}\right)$ on soil $\mathrm{CH}_{4}$ flux and methanotroph and methanogen abundance, diversity, and community structure in a Moso bamboo (Phyllostachys edulis) forest in subtropical China. $\mathrm{N}$ addition significantly increased methanogen abundance but reduced both methanotroph and methanogen diversity. Methanotroph and methanogen community structures under the $\mathrm{N}$ deposition treatments were significantly different from those of the control. In N deposition treatments, the relative abundance of Methanoculleus was significantly lower than that in the control. Soil pH was the key factor regulating the changes in

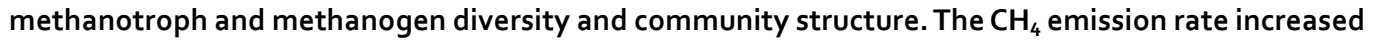
with $\mathrm{N}$ addition and was negatively correlated with both methanotroph and methanogen diversity but positively correlated with methanogen abundance. Overall, our results suggested that $\mathrm{N}$ deposition can suppress $\mathrm{CH}_{4}$ uptake by altering methanotroph and methanogen abundance, diversity, and community structure in subtropical Moso bamboo forest soils.

Methane $\left(\mathrm{CH}_{4}\right)$ is the second-most important anthropogenic greenhouse gas after carbon dioxide ${ }^{1}$ and is responsible for $15 \%$ of the effects of global warming ${ }^{2}$. The atmospheric concentration of $\mathrm{CH}_{4}$ has been increasing rapidly in the past decades ${ }^{1,3,4}$ owing to a growing imbalance between production and consumption ${ }^{5}$. In soils, $\mathrm{CH}_{4}$ is mainly produced by methanogens during organic decomposition ${ }^{6}$; in aerobic soils, it is then consumed via oxidation by methanotrophs ${ }^{7}$, whereas in anaerobic conditions, it is consumed by anaerobic methanotrophs ${ }^{8,9}$, such as sulfate-dependent, nitrate- or nitrite-dependent, and metal-dependent $\mathrm{CH}_{4}$ oxidizers ${ }^{10}$. Methanotrophs are classified into two groups (type-I and type-II) according to their phylogenetic affiliations, carbon assimilation pathways, and phospholipid fatty acid compositions ${ }^{11}$ and the terms (type-I and type-II) are frequently used and adapted to the increasing diversity of methanotrophs ${ }^{12}$. Numerous studies have demonstrated that changes in methanogens and methanotrophs activities depend on temperature, moisture, and nutrient availability ${ }^{13-15}$. In particular, nitrogen $(\mathrm{N})$ can directly affect methanotrophs and methanogens at the cellular level or indirectly influence them by inducing changes in the soil ecosystem ${ }^{16}$.

The annual input of reactive anthropogenic $\mathrm{N}$ in soils has increased more than tenfold in the past 150 years, and this trend is predicted to intensify by 2 - or threefold in the coming years ${ }^{17-19}$. The largest $\mathrm{N}$ increases are likely to continue occurring in both East and South Asia ${ }^{20,21}$, particularly in subtropical China ${ }^{22,23}$. The response of methanotrophs to $\mathrm{N}$ addition and the subsequent change in $\mathrm{CH}_{4}$ emission rates are inconsistent; multiple contradictory results have been published, including evidence of methanotroph inhibition ${ }^{24,25}$, stimulation ${ }^{26,27}$,

\footnotetext{
${ }^{1}$ Center for Ecological Forecasting and Global Change, College of Forestry, Northwest A\&F University, Yangling 712100, China. 'State Key Laboratory of Subtropical Silviculture, Zhejiang A\&F University, Hangzhou 311300, China. ${ }^{3}$ Department of Biology Sciences, Institute of Environment Sciences, University of Quebec at Montreal, Case Postale 8888, Succursale Centre-Ville, Montreal H3C3P8, Canada. ${ }^{\square}$ email: peng.changhui@uqam.ca; songxinzhang@gmail.com
} 
and null responses ${ }^{28}$. Many studies have also highlighted the highly complex nature of the effects of $\mathrm{N}$ addition on methanogen activity in soils ${ }^{7}$. For example, Shang et al. ${ }^{29}$ demonstrated that the addition of urea stimulates methanogen activity in rice soils owing to an increase in biomass production. In contrast, the application of $\mathrm{N}$ fertilizer (100 and $300 \mathrm{~kg} \mathrm{~N} \mathrm{ha}^{-1} \mathrm{yr}^{-1}$ ) has been shown to decrease methanogen activity in rice soils ${ }^{30}$. Furthermore, the abundance, diversity, and community composition of methanotrophs and methanogens are key determinants of their ecological functions ${ }^{31-33}$. Some studies have found that $\mathrm{N}$ addition affects the abundance and community composition of methanotrophs and methanogens ${ }^{15,34-36}$. For example, Aronson et al. ${ }^{15}$ found that ammonium nitrate addition $\left(67 \mathrm{~kg} \mathrm{NH}_{4} \mathrm{NO}_{3} \mathrm{ha}^{-1} \mathrm{yr}^{-1}\right)$ increases methanotroph and methanogen abundance and the richness of methanotrophs in poorly-drained pine forest soil but decreases the richness of methanotrophs and methanogens in well-drained pine forest soil. The application of $\mathrm{N}$ fertilizer (compound fertilizer + urea $20.8 \mathrm{~kg} \mathrm{~N} \mathrm{ha}^{-1} \mathrm{yr}^{-1}$ ) decreases the abundance of methanotrophs and methanogens and significantly affects type-I methanotrophs but does not affect methanogen community composition in orchard plots ${ }^{35}$. In addition, the effects of different $\mathrm{N}$ application rates and types $\left(\mathrm{NH}_{4}{ }^{+}, \mathrm{NO}_{3}{ }^{-}\right.$, or urea) on methanotroph communities are different and may depend on the ecosystem type ${ }^{37,38}$. Zhang et al. ${ }^{39}$ found that $\mathrm{NH}_{4}{ }^{+}$addition $\left(45 \mathrm{~kg} \mathrm{~N} \mathrm{ha}^{-1} \mathrm{yr}^{-1}\right)$ decreases the abundance of methanotrophs and affects methanotroph community composition in temperate forest soils. Mohanty et al. ${ }^{40}$ observed that the application of $\mathrm{NH}_{4} \mathrm{NO}_{3}\left(60 \mathrm{~kg} \mathrm{~N} \mathrm{ha}^{-1} \mathrm{yr}^{-1}\right)$ increases the abundance of type-I methanotrophs but decreases that of type-II methanotrophs in incubated forest soils. In rice soil, the addition of $\mathrm{NH}_{4}{ }^{+}$suppresses type-II but stimulates type-I methanotrophs, whereas the addition of $\mathrm{NO}_{3}{ }^{-}$increases both types of methanotrophs ${ }^{41}$ and that of urea does not alter the methanotroph community ${ }^{42}$. Urea and ammonia addition significantly increase the diversity of methanotrophs, whereas $\mathrm{NO}_{3}{ }^{-}$addition only favors type-I methanotrophs in an alpine marsh meadow in the Qinghai-Tibetan plateau ${ }^{38}$. Jang et al. ${ }^{43}$ found that $\mathrm{NH}_{4} \mathrm{NO}_{3}$ addition inhibits type-I methanotrophs in temperate forest soils. Most of these studies either only observed methanotrophs $\mathrm{s}^{39,43}$, were performed in manipulation experiments ${ }^{40}$, or were carried out in temperate forest soils to assess the effects of $\mathrm{N}$ addition on methanotrophs and methanogens ${ }^{15}$. Therefore, more information regarding different forest soils, especially tropical or subtropical forest soils, is necessary to advance our understanding of methanotroph and methanogen dynamics under conditions of increasing $\mathrm{N}$ deposition.

In China, there are 4.43 million hectares of Moso bamboo (Phyllostachys edulis) forest, which comprise $70 \%$ of the total bamboo forest area and $2 \%$ of the total forest area in the country ${ }^{44}$. Moso bamboo can grow to a height of $10-20 \mathrm{~m}$ in $40-50$ days $^{45}$. In subtropical China, the mean annual bulk $\mathrm{N}$ deposition has reached $30 \mathrm{~kg} \mathrm{~N} \mathrm{ha}^{-1} \mathrm{yr}^{-146}$ and is predicted to remain high for the foreseeable future ${ }^{20,47}$. Several field studies have observed that simulated $\mathrm{N}$ deposition suppresses $\mathrm{CH}_{4}$ uptake in tropical forests in southern China, which may be attributed to the increase in inorganic $\mathrm{N}$, soil $\mathrm{Al}^{3+}$ release, and the drop in $\mathrm{pH}$ owing to $\mathrm{N}$ addition ${ }^{48,49}$. In addition, our previous study in the same site found that $\mathrm{N}$ addition significantly reduces soil $\mathrm{CH}_{4}$ uptake in Moso bamboo forests, which is attributed to abiotic factors, such as the change in soil $\mathrm{NH}_{4}{ }^{+}$concentration and $\mathrm{pH}^{50}$. Previous studies have demonstrated that the abundance, diversity, and community structure of methanotrophs and methanogens are mainly influenced by soil $\mathrm{pH}^{51,52}, \mathrm{NH}_{4}{ }^{+}$concentration ${ }^{16}$, and soil substrate ${ }^{53}$. For example, $\mathrm{pH}$ has a negative effect on upland soil cluster (USC)- $\alpha$ and a positive effect on USC- $\gamma$ abundance ${ }^{54}$. USC- $\alpha$ has been detected in mostly acidic upland soils ${ }^{55}$, whereas USC- $\gamma$ is detected in alkaline upland soils ${ }^{56,57}$. Furthermore, few studies have linked $\mathrm{CH}_{4}$ fluxes to the abundances of methanotrophs and methanogens and the environmental factors influencing their abundances ${ }^{54}$. Thus, it is equally important to investigate $\mathrm{N}$ deposition on the relationship between soil $\mathrm{CH}_{4}$ flux and the abundance and community structure of the methanotrophs and methanogens in Moso bamboo forests.

The $p m o A$ gene, which is commonly recognized as a phylogenetic marker of methanotrophs in ecological studies, encodes the membrane-bound subunit of particulate methane monooxygenase (MMO) ${ }^{58}$. MMOs catalyze the conversion of $\mathrm{NH}_{4}{ }^{+}$and dioxygen to methanol and water, with one atom of the dioxygen molecule being incorporated into methanol and the other into water ${ }^{59}$. The $m c r A$ gene encodes the alpha subunit of methyl coenzyme $\mathrm{M}$ reductase (MCR), which is the key catabolic enzyme of methanogens ${ }^{60}$; it catalyzes the reduction of a methyl group bound to coenzyme $\mathrm{M}$, releasing $\mathrm{CH}_{4}{ }^{61}$. Therefore, it is widely accepted that the abundance and community composition of methanotrophs and methanogens are characterized by the $m c r A$ and $p m o A$ genes, respectively. Here, we investigated how $\mathrm{N}$ deposition affects methanotroph and methanogen abundance, diversity, and community structure in a Moso bamboo forest using the $p m o A$ and $m c r A$ genes. This study tested the following hypotheses: (1) N addition will decrease methanotroph abundance and influence methanotroph community structure and diversity; (2) $\mathrm{N}$ addition will decrease methanogen abundance and influence methanogen community structure and diversity; and (3) $\mathrm{N}$ addition will inhibit $\mathrm{CH}_{4}$ uptake by altering methanotroph and methanogen abundance, diversity, and community structure. The information is important to our understanding of how increasing $\mathrm{N}$ deposition could change the abundance, community structure, and diversity of soil methanotroph and methanogen and the methane flux they drive in the Moso bamboo plantations in the future.

\section{Results}

Soil properties. $\mathrm{N}$ deposition has an important impact on soil physicochemical properties (Table 1). The highest soil $\mathrm{pH}$ (4.9) was recorded from the control treatment; it was significantly higher than that in the other treatments $(P<0.05)$, especially compared with the $\mathrm{N} 90$ treatment $(\mathrm{pH} 4.2)$. Concentrations of $\mathrm{NO}_{3}{ }^{-}$and $\mathrm{NH}_{4}{ }^{+}$ and the $\mathrm{C} / \mathrm{N}$ ratio were higher in the $\mathrm{N} 90$ treatment than in the control treatment $(P<0.05)$. Compared with the control treatment, the higher amount of $\mathrm{N}$ addition (N90) significantly decreased moisture and the concentrations of soil organic carbon (SOC) and total nitrogen (TN). The concentration of available phosphorus (AP) increased after $\mathrm{N}$ addition compared with the control treatment $(P<0.05)$. 


\begin{tabular}{|l|l|l|c|c|}
\hline Properties & Control & N30 & N60 & N90 \\
\hline Moisture (\%) & $34.2 \pm 1.9 \mathrm{a}$ & $32.3 \pm 2.7 \mathrm{~b}$ & $35.9 \pm 2.9 \mathrm{a}$ & $32.0 \pm 3.6 \mathrm{~b}$ \\
\hline $\mathrm{pH}$ & $4.9 \pm 0.07 \mathrm{a}$ & $4.4 \pm 0.03 \mathrm{c}$ & $4.5 \pm 0.01 \mathrm{~b}$ & $4.2 \pm 0.03 \mathrm{~d}$ \\
\hline $\mathrm{SOC}\left(\mathrm{g} \mathrm{kg}^{-1}\right)$ & $26.2 \pm 2.6 \mathrm{a}$ & $22.7 \pm 1.9 \mathrm{c}$ & $25.6 \pm 3.7 \mathrm{ab}$ & $24.9 \pm 2.3 \mathrm{~b}$ \\
\hline $\mathrm{MBC}\left(\mathrm{mg} \mathrm{kg}^{-1}\right)$ & $637.1 \pm 62.7 \mathrm{~b}$ & $574.3 \pm 14.7 \mathrm{~b}$ & $803.3 \pm 74.7 \mathrm{a}$ & $718.3 \pm 27.8 \mathrm{ab}$ \\
\hline $\mathrm{DOC}\left(\mathrm{mg} \mathrm{kg}^{-1}\right)$ & $234.0 \pm 17.1 \mathrm{ab}$ & $251.3 \pm 17.5 \mathrm{a}$ & $215.7 \pm 6.6 \mathrm{~b}$ & $206.1 \pm 13.2 \mathrm{~b}$ \\
\hline $\mathrm{TN}\left(\mathrm{g} \mathrm{kg}^{-1}\right)$ & $2.2 \pm 0.02 \mathrm{a}$ & $1.8 \pm 0.03 \mathrm{c}$ & $2.1 \pm 0.02 \mathrm{~b}$ & $1.9 \pm 0.03 \mathrm{c}$ \\
\hline $\mathrm{NO}_{3}^{-}\left(\mathrm{mg} \mathrm{kg}^{-1}\right)$ & $16.1 \pm 1.5 \mathrm{c}$ & $12.8 \pm 1.2 \mathrm{~d}$ & $24.7 \pm 2.5 \mathrm{a}$ & $18.2 \pm 1.7 \mathrm{~b}$ \\
\hline $\mathrm{NH}_{4}^{+}\left(\mathrm{mg} \mathrm{kg}^{-1}\right)$ & $10.9 \pm 1.3 \mathrm{~b}$ & $11.3 \pm 1.7 \mathrm{~b}$ & $7.0 \pm 0.5 \mathrm{c}$ & $18.9 \pm 2.4 \mathrm{a}$ \\
\hline $\mathrm{C} / \mathrm{N}$ & $11.7 \pm 1.3 \mathrm{~b}$ & $12.3 \pm 0.7 \mathrm{~b}$ & $11.8 \pm 1.1 \mathrm{~b}$ & $13.4 \pm 0.9 \mathrm{a}$ \\
\hline $\mathrm{AP}\left(\mathrm{mg} \mathrm{kg}^{-1}\right)$ & $7.3 \pm 0.9 \mathrm{~d}$ & $32.0 \pm 1.2 \mathrm{a}$ & $20.1 \pm 1.6 \mathrm{~b}$ & $14.6 \pm 1.1 \mathrm{c}$ \\
\hline
\end{tabular}

Table 1. Average physicochemical properties of the soil in the Moso bamboo forest study plots. SOC soil organic carbon, $M B C$ microbial biomass carbon, $D O C$ dissolved organic carbon, $T N$ total nitrogen, $\mathrm{NO}_{3}{ }^{-}$ nitrate, $\mathrm{NH}_{4}{ }^{+}$ammonium, $\mathrm{C} / \mathrm{N}$ carbon/nitrogen, $A P$ available phosphorous. Mean $\pm \mathrm{SD}(\mathrm{n}=3)$. Different lowercase letters indicate significant differences at $P<0.05$ for all treatments.

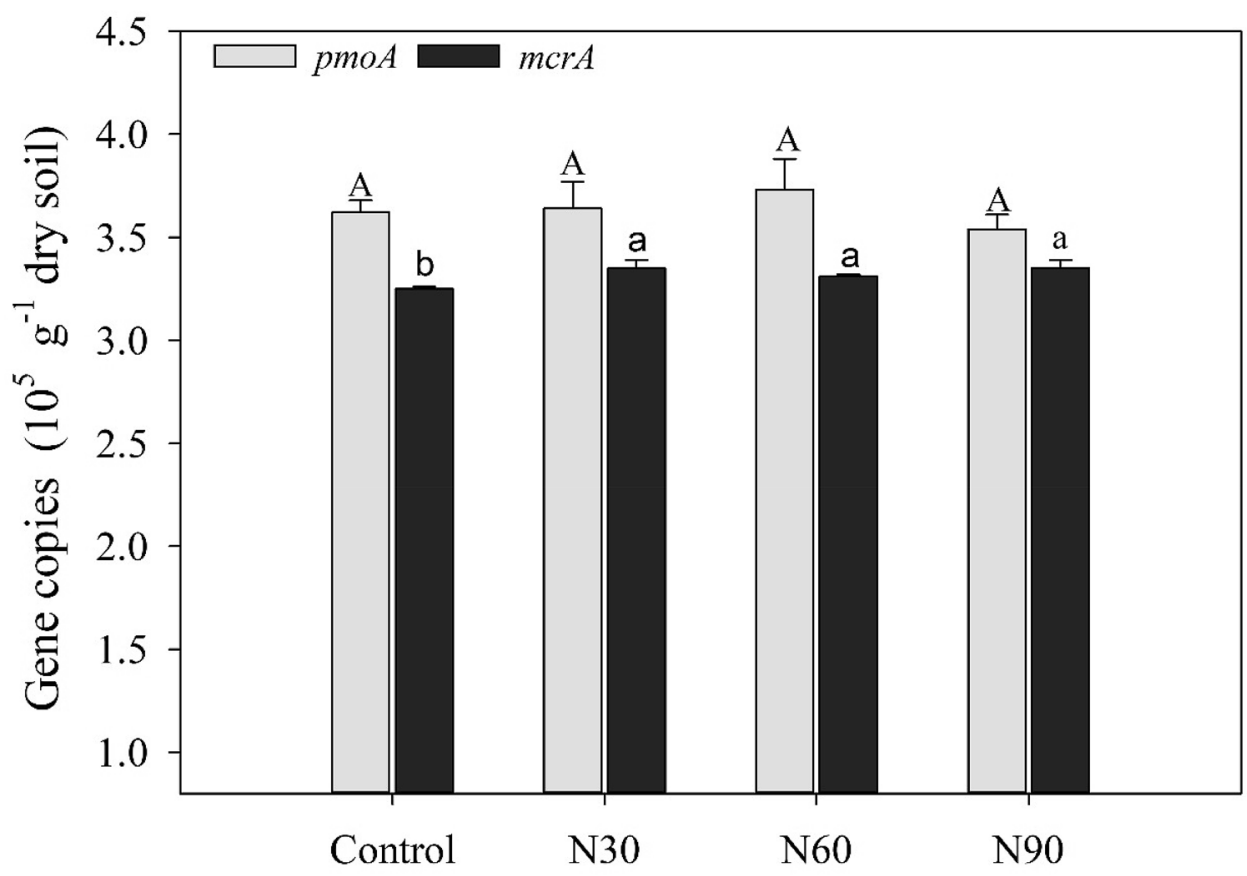

Treatments

Figure 1. Methanotroph $(p m o A)$ and methanogen $(m c r A)$ abundance under different $\mathrm{N}$ addition treatments in Moso bamboo forest soil (Control, $0 \mathrm{~kg} \mathrm{~N} \mathrm{ha}^{-1} \mathrm{yr}^{-1}$; N30, $30 \mathrm{~kg} \mathrm{~N} \mathrm{ha}^{-1} \mathrm{yr}^{-1}$; $\mathrm{N} 60,60 \mathrm{~kg} \mathrm{~N} \mathrm{ha}^{-1} \mathrm{yr}^{-1}$; N90, $\left.90 \mathrm{~kg} \mathrm{~N} \mathrm{ha}^{-1} \mathrm{yr}^{-1}\right)$. Different upper-case letters indicate significant differences $(P<0.05)$ between treatments for methanotrophs and different lower-case letters indicate significant differences $(P<0.05)$ between treatments for methanogens.

Methanotroph and methanogen abundance. $\mathrm{N}$ addition did not significantly affect the abundance of the $p m o A$ gene $(P>0.05$; Fig. 1). The abundance of the $m c r A$ gene in the control treatment was significantly lower than that in the $\mathrm{N}$ addition treatments $(P<0.05$; Fig. 1$)$. The correlation analysis revealed that the abundance of the $p m o A$ gene was negatively correlated with the soil $\mathrm{NH}_{4}{ }^{+}$concentration $(P<0.05)$. The abundance of the $m c r A$ gene was positively correlated with the AP concentration $(P<0.05)$ but negatively correlated with soil SOC and TN concentrations and $\mathrm{pH}(P<0.05$; Fig. 2).

Methanotroph and methanogen diversity. The Shannon and Chaol indexes were used to estimate soil microbial diversity and richness among all treatments (Fig. 3). The values of the Shannon and Chao1 indexes for methanotrophs were significantly lower in the $\mathrm{N}$ addition treatments than in the control treatment $(P<0.05)$. The Chaol index for methanogens decreased significantly after $\mathrm{N}$ addition in all treatments $(P<0.05)$, whereas 


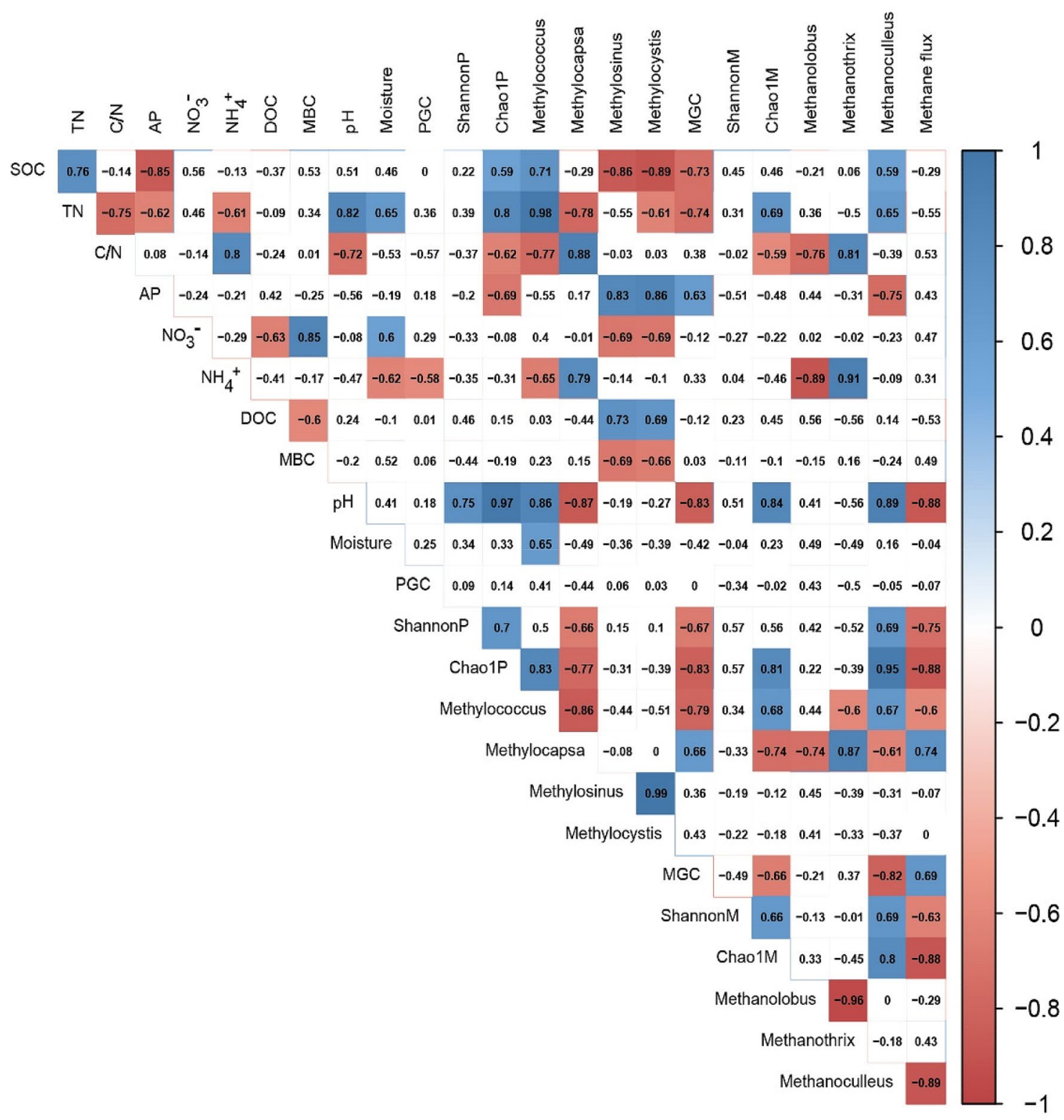

Figure 2. Pearson's correlation coefficients (R) for relationships between soil properties and methanotroph and methanogen abundance, diversity, and dominant community, and $\mathrm{CH}_{4}$ flux. SOC, soil organic carbon; $\mathrm{MBC}$, microbial biomass carbon; DOC, dissolved organic carbon; TN, total nitrogen; $\mathrm{NO}_{3}{ }^{-}$, nitrate; $\mathrm{NH}_{4}{ }^{+}$, ammonium; $\mathrm{C} / \mathrm{N}$, carbon/nitrogen; AP, available phosphorous; PGC, abundance of $p m o A$ gene; ShannonP, Shannon index for methanotrophs; Chao1P, Chaol index for methanotrophs; MGC, abundance of mcrA gene; ShannonM, Shannon index for methanogens; Chao $1 \mathrm{M}$, Chaol index for methanogens. The color and numbers shown indicate the strength and sign of the correlation. Lack of color indicates no significant correlations $(P>0.05)$. Cool colors indicate significant and positive correlations $(P<0.05)$, whereas warm colors indicate significant and negative correlations $(P<0.05)$.

the Shannon index only decreased significantly in the N60 treatment $(P<0.05)$. The Shannon and Chaol indexes for methanotrophs were positively correlated with soil $\mathrm{pH}(P<0.05)$. In addition, the Chaol index for methanotrophs was negatively correlated with AP concentration $(P<0.05)$ and the $\mathrm{C} / \mathrm{N}$ ratio $(P<0.05)$ but positively correlated with SOC $(P<0.05)$ and TN $(P<0.05$; Fig. 2$)$ concentration. Pearson's correlation analysis revealed that the Chaol index for methanogens was positively correlated with soil $\mathrm{pH}(P<0.05)$ and TN concentration $(P<0.05)$ but negatively correlated with the $\mathrm{C} / \mathrm{N}$ ratio $(P<0.05)$.

Methanotroph and methanogen community structure. The number of operational taxonomic units (OTUs) detected varied across the $\mathrm{N}$ addition treatments (Fig. S1). The pmoA OTUs ranged from 231 in the N90 treatment to 349 in the control treatment. For $m c r A$, a total of 1050 OTUs were detected in the control treatment; in the N30, N60, and N90 treatments, 898, 867, and 1157 OTUs were detected, respectively. When 

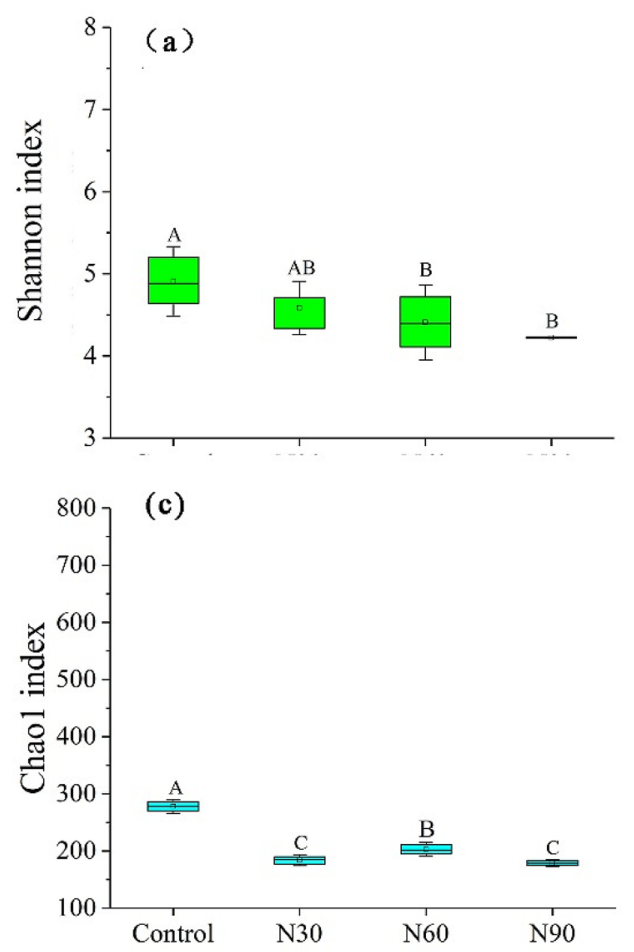

(b)

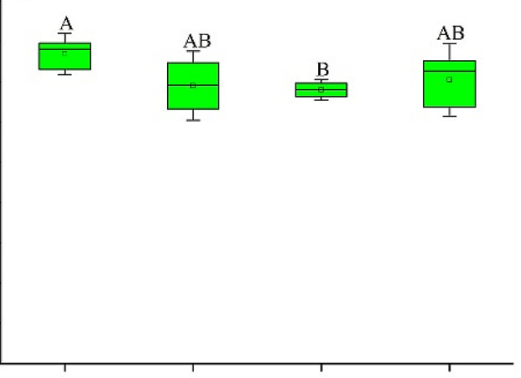

(d)

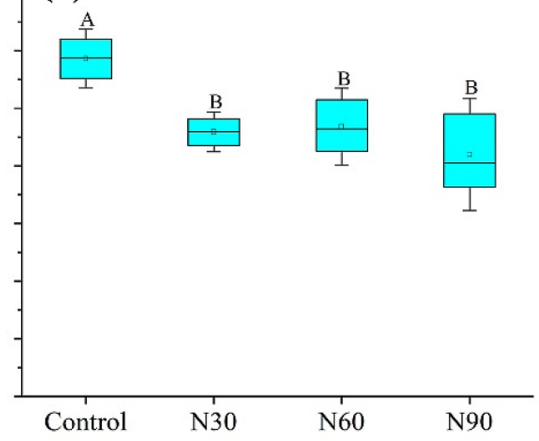

Figure 3. Shannon and Chaol indexes for methanotrophs $(\mathbf{a}, \mathbf{c})$ and methanogens $(\mathbf{b}, \mathbf{d})$ under different $\mathrm{N}$ addition treatments. Different letters indicate significant differences $(P<0.05)$ between treatments.
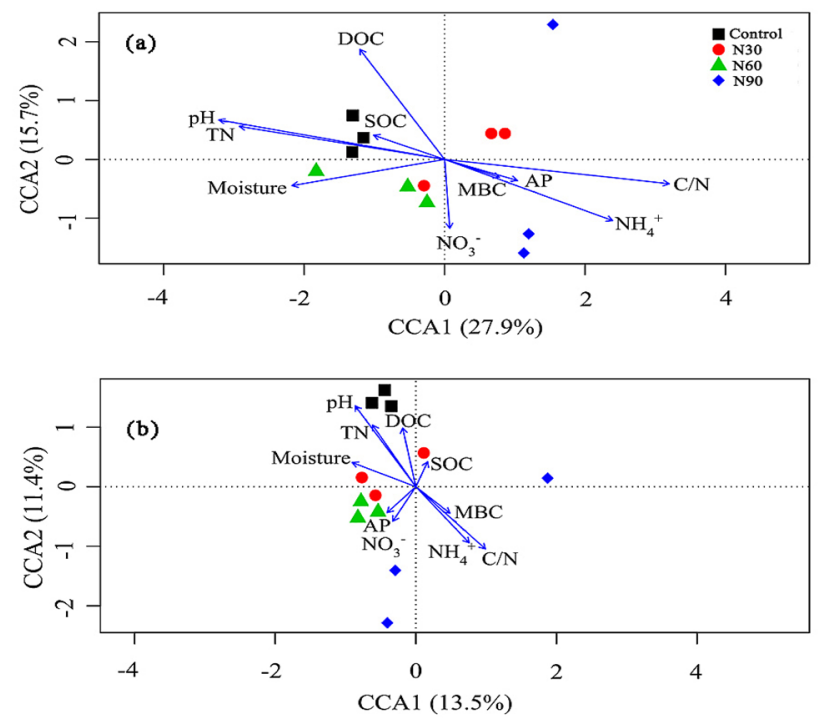

Figure 4. Results of the canonical correlation analysis (CCA) of the relationships between soil physicochemical properties and methanotroph (a) and methanogen (b) community structure in all treatments.

the four treatments were compared, we found that they shared 231 OTUs. Cluster analysis showed that the methanotroph and methanogen community structure in the control treatment was different from the structure observed in the $\mathrm{N}$ deposition treatments (Fig. S2). In addition, ANOSIM showed that there were significant differences between control and $\mathrm{N}$ addition treatments for the methanotroph $(\mathrm{R}=0.75, P<0.001)$ and methanogen $(\mathrm{R}=0.58, P<0.001)$ community structure (Table $\mathrm{S} 1)$. The canonical correspondence analysis showed that soil characteristics were related to the methanotroph and methanogen community structure (Fig. 4). Furthermore, a Monte Carlo permutation test showed that soil $\mathrm{pH}$, the $\mathrm{C} / \mathrm{N}$ ratio, and $\mathrm{TN}$ and $\mathrm{NH}_{4}{ }^{+}$concentration $(P<0.05)$ were the primary factors that influenced methanotroph communities (Table 2). For methanogens, soil $\mathrm{pH}$ and 


\begin{tabular}{|l|l|l|l|l|}
\hline \multirow{2}{*}{ Soil variables } & \multicolumn{2}{|l|}{ Methanotroph } & \multicolumn{2}{l|}{ Methanogen } \\
\cline { 2 - 5 } & $\mathbf{r}^{2}$ & $\boldsymbol{P}$ & $\mathbf{r}^{2}$ & $\boldsymbol{P}$ \\
\hline Moisture & 0.385 & 0.142 & 0.287 & 0.252 \\
\hline $\mathrm{pH}$ & $0.847^{*}$ & 0.002 & $0.786^{*}$ & 0.005 \\
\hline $\mathrm{SOC}$ & 0.093 & 0.684 & 0.062 & 0.843 \\
\hline $\mathrm{MBC}$ & 0.055 & 0.841 & 0.132 & 0.717 \\
\hline $\mathrm{DOC}$ & 0.374 & 0.164 & 0.305 & 0.366 \\
\hline $\mathrm{TN}$ & $0.696^{*}$ & 0.009 & 0.435 & 0.124 \\
\hline $\mathrm{NO}_{3}{ }^{-}$ & 0.1 & 0.698 & 0.134 & 0.705 \\
\hline $\mathrm{NH}_{4}{ }^{+}$ & $0.537^{*}$ & 0.041 & 0.437 & 0.202 \\
\hline $\mathrm{C} / \mathrm{N}$ & $0.816^{*}$ & 0.001 & $0.625^{*}$ & 0.037 \\
\hline $\mathrm{AP}$ & 0.093 & 0.698 & 0.107 & 0.741 \\
\hline
\end{tabular}

Table 2. Monte Carlo permutation test correlations between methanotroph and methanogen community structure and soil physicochemical properties. ${ }^{\star}$ Indicates significant effects $(P<0.05)$.
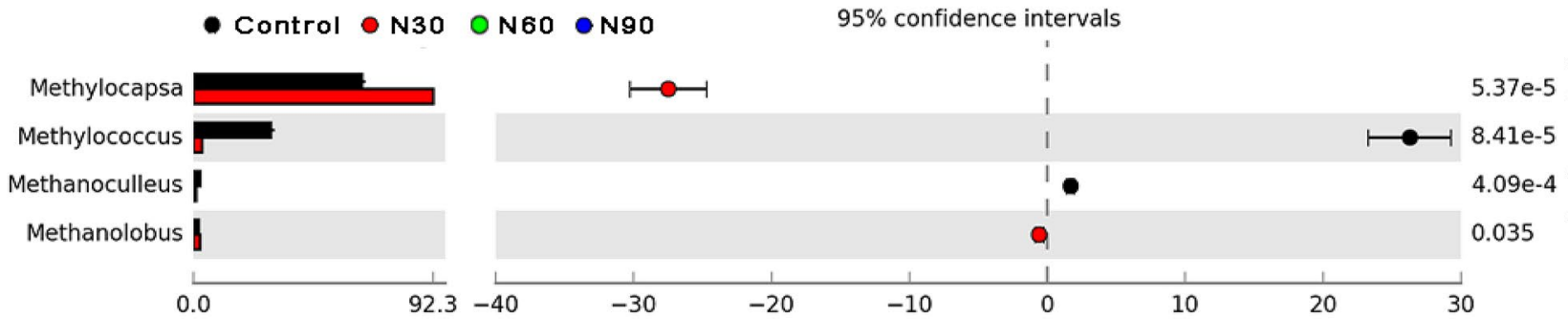

$95 \%$ confidence intervals
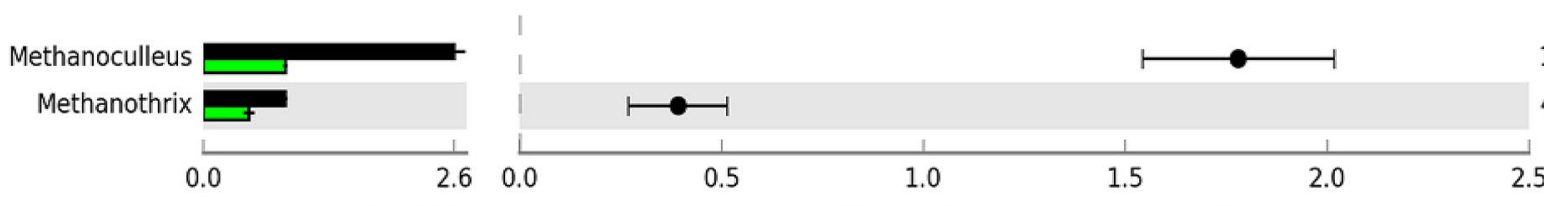

$1.57 \mathrm{e}-4$

$4.50 \mathrm{e}-3$

1.0
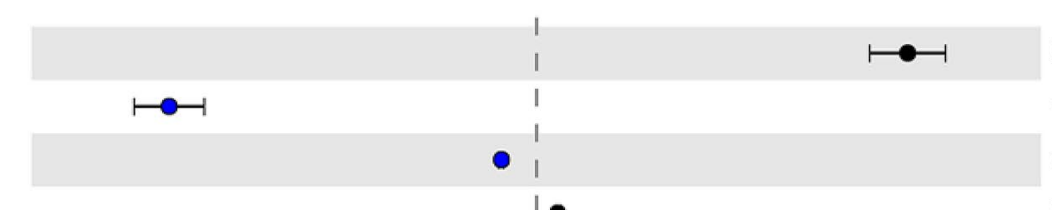

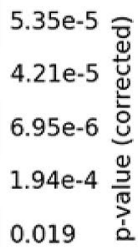
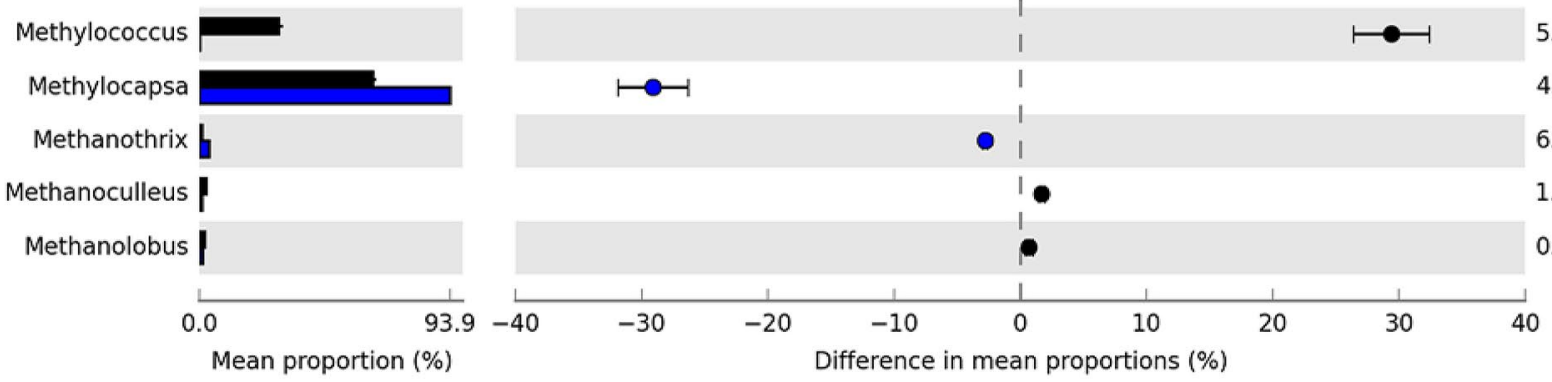

Figure 5. Dominant methanotrophs $(p m o A)$ and methanogens $(m c r A)$ under $\mathrm{N}$ addition treatments.

the $\mathrm{C} / \mathrm{N}$ ratio were the two most important contributors to the variation in methanogen communities $(P<0.05$; Table 2).

Dominant methanotroph and methanogen groups. At the methanotroph genus level, four genera were most abundant (Methylococcus, Methylocapsa, Methylosinus, and Methylocystis) and presented relative abundances $>1 \%$ in all treatments (Fig. S2). Methylocapsa and Methylococcus were the two most abundant genera across all treatments and together accounted for $80.32-97.24 \%$ of the $p m o A$ gene sequences. The relative abundance of Methylocapsa in the N addition treatments (N30 and N90) was significantly higher than that in the control treatment (Fig. 5), whereas Methylococcus showed the opposite trend. The relative abundance of Methylocapsa was negatively correlated with soil $\mathrm{pH}$ and $\mathrm{TN}$ concentration $(P<0.05)$ but positively correlated with the $\mathrm{C} / \mathrm{N}$ ratio and $\mathrm{NH}_{4}{ }^{+}$concentration $(P<0.05)$, whereas Methylococcus presented the opposite trend $(P<0.05$; Fig. 2). The relative abundance of Methylosinus and Methylocystis was negatively correlated with SOC, microbial biomass carbon $(\mathrm{MBC})$, and $\mathrm{NO}_{3}{ }^{-}$concentrations $(P<0.05)$ but positively correlated with soil AP and dissolved organic carbon (DOC) concentrations $(P<0.05$; Fig. 2$)$. 


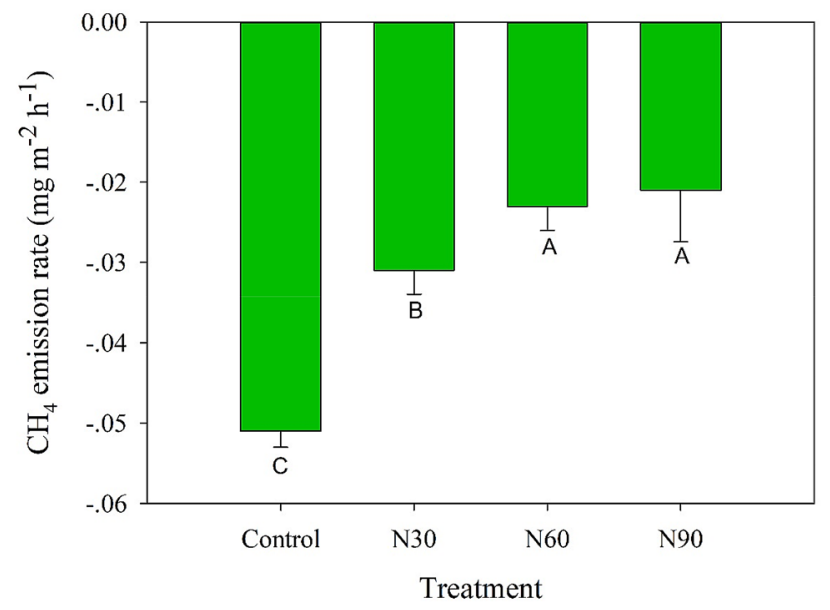

Figure 6. $\mathrm{CH}_{4}$ emission rate in February 2018 under different $\mathrm{N}$ addition treatments.

For methanogens, Methanolobus, Methanothrix, and Methanoculleus (relative abundance $>1 \%$ ) were the dominant genera across all sequence data (Fig. S2). The $\mathrm{N}$ addition treatments significantly decreased the relative abundance of Methanoculleus (Fig. 5). The relative abundance of Methanothrix was positively correlated with the $\mathrm{C} / \mathrm{N}$ ratio and $\mathrm{NH}_{4}{ }^{+}(P<0.05)$ concentration, whereas Methanolobus presented the opposite trend. Methanoculleus was positively correlated with soil $\mathrm{pH}(P<0.05)$ and SOC $(P<0.05)$ and TN $(P<0.05)$ concentrations but negatively correlated with soil AP concentration $(P<0.05$; Fig. 2$)$.

$\mathrm{CH}_{4}$ flux. $\quad \mathrm{CH}_{4}$ flux in the $\mathrm{N}$ addition treatments was significantly higher (39.2-58.8\%) than that in the control treatment (Fig. 6). The $\mathrm{CH}_{4}$ flux was positively correlated with methanogen abundance and the relative abundance of Methylocapsa but negatively correlated with the Shannon and Chaol indexes for both methanotrophs and methanogens, the relative abundance of Methanoculleus and Methylococcus, and $\mathrm{pH}(P<0.05 ;$ Fig. 2).

\section{Discussion}

Effect of $\mathrm{N}$ addition on methanotroph abundance, diversity, and community structure. $\mathrm{N}$ addition did not significantly affect the abundance of the $p m o A$ gene in the soil from the Moso bamboo forest; this did not support the first hypothesis that $\mathrm{N}$ addition would decrease methanotroph abundance. However, previous studies have found that $\mathrm{N}$ addition reduces the abundance of the $p m o A$ gene in rice soils ${ }^{34}$ and temperate forest soils ${ }^{39}$. These reductions may be the result of high $\mathrm{NH}_{4}{ }^{+}$concentrations reducing methanotroph activity through inhibition or competition for $\mathrm{MMO}^{16}$. Nitrite toxicity owing to the nitrification of $\mathrm{NH}_{4}{ }^{+}$may also inhibit methanotroph activity ${ }^{62}$. In our study, the $\mathrm{NH}_{4}{ }^{+}$soil concentration was significantly and negatively correlated with methanotroph abundance, which supports the aforementioned conclusion that a high $\mathrm{NH}_{4}^{+}$ concentration inhibits methanotroph abundance. Low levels of N addition (N30 treatment) did not significantly affect soil $\mathrm{NH}_{4}{ }^{+}$concentration in the present study, which indirectly indicates that $\mathrm{N}$ addition has no effect on pmoA abundance.

The Chaol index presents species richness information and is sensitive to changes in rare species ${ }^{63}$, whereas the Shannon index accounts for both species abundance and evenness ${ }^{64}$. The effect of $\mathrm{N}$ addition on both the Shannon and Chaol indexes was negative, suggesting an overall decline in soil methanotroph diversity. Although few studies have focused on methanotroph diversity in forest soils ${ }^{15}$, some studies have demonstrated that $\mathrm{N}$ addition significantly decreases soil microbial diversity ${ }^{65-68}$. A meta-analysis found that $\mathrm{N}$ addition decreases soil microbial (bacteria and fungi) diversity among different ecosystems $\mathrm{s}^{33}$ owing to a decrease in soil $\mathrm{pH}^{69,70}$. Our results also found that soil $\mathrm{pH}$ was lower in the $\mathrm{N}$ addition treatments and positively correlated with methanotroph diversity, which supports the conclusion that $\mathrm{N}$ addition reduces methanotroph diversity. The underlying mechanism may be that soil $\mathrm{pH}$ influences the growth of some microbial functional groups ${ }^{71}$. Low $\mathrm{pH}$ leads to the leaching of magnesium and calcium and the mobilization of aluminum ${ }^{72}$. When this occurs, some microbes may suffer magnesium- or calcium-limitation or aluminum toxicity, which result in decreased microbial diversity ${ }^{33,66}$.

$\mathrm{N}$ addition significantly influenced the methanotroph community structure and the relative abundance of type-I and type-II methanotrophs. This result supports the first hypothesis of this study and is consistent with the findings of Zhang et al. ${ }^{39}$ and Jang et al. ${ }^{43}$, who found that $\mathrm{N}$ addition significantly affects methanotroph community structure. These studies demonstrated that $\mathrm{N}$ addition affects the community structure of soil microbes by changing the inorganic $\mathrm{N}$ concentration, the $\mathrm{C} / \mathrm{N}$ ratio, and $\mathrm{pH}$ in soils ${ }^{33,73,74}$. In our study, the changes in soil TN and $\mathrm{NH}_{4}{ }^{+}$concentrations, the $\mathrm{C} / \mathrm{N}$ ratio, and $\mathrm{pH}$ owing to $\mathrm{N}$ addition influenced the methanotroph genera present and subsequently altered the composition of the microbial community. One possible explanation for this result is that soil microbial communities are directly influenced by soil $\mathrm{pH}$ given that most microbial taxa exhibit a relatively narrow $\mathrm{pH}$ tolerance for growth ${ }^{69,75}$. For example, a decrease in optimum growth of only $25 \%$ would lead to a population being rapidly outcompeted by other microbial populations that were not growth-impeded ${ }^{69}$. These narrow $\mathrm{pH}$ optima for microbes would explain the strong relationship between microbial community 
composition and soil $\mathrm{pH}$. Furthermore, previous studies found that different methanotrophs have different $\mathrm{pH}$ optima $^{11,51}$. The $\mathrm{C} / \mathrm{N}$ ratio also plays an important role in the regulation of microbial community structure $\mathrm{e}^{76}$, which may be attributed to microorganisms using substrates with different $\mathrm{C} / \mathrm{N}$ ratios ${ }^{77}$.

In the present study, we found that the soil methanotroph community was dominated by type-II methanotrophs (Methylocapsa, Methylosinus, and Methylocystis) in all treatments. In particular, Methylocapsa was the most abundant indicator of methanotroph species and accounted for $77.5 \%$ of all sequences. Previous studies have reported that type-II methanotrophs are the predominant group in forest soils ${ }^{43,78}$, which may be the result of the abundance of type-I and type-II methanotrophs being affected by the concentration of $\mathrm{CH}_{4}{ }^{79}$. Type-II methanotrophs have been found to dominate under low $\mathrm{CH}_{4}$ concentrations, whereas type-I methanotrophs have been found to dominate under high $\mathrm{CH}_{4}$ concentrations ${ }^{43}$. Bender and Conrad ${ }^{80}$ demonstrated that forest soils are exposed to low $\mathrm{CH}_{4}$ concentrations. Therefore, type-II methanotrophs are the predominant group in Moso bamboo forest soils. In addition, some studies have shown that Methylocapsa is a member of USC- $\alpha$ in forest soils with an acidic $\mathrm{pH}^{81,82}$. In this study, the relative abundance of Methylocapsa was significantly and negatively correlated with soil $\mathrm{pH}(P<0.01)$, which was consistent with the finding of Täumer et al..$^{38}$ that there is a negative correlation between the $\mathrm{pH}$ and USC- $\alpha$. However, the relative abundance of Methylococcus was strongly and positively correlated with soil $\mathrm{pH}(P<0.01)$, which indicates that type-I methanotrophs were not able to adapt to the lower $\mathrm{pH}$ conditions of the soil in the $\mathrm{N}$ addition treatments. These results demonstrated that $\mathrm{pH}$ played an important role in altering the community composition of soil methanotrophs. Overall, the effects of $\mathrm{N}$ addition on methanotroph community structures in Moso bamboo forest soils were consistent with the results from temperate forest soils $\mathrm{s}^{39,43}$. These results indicate that the response of methanotroph community structures to $\mathrm{N}$ addition in a subtropical forest ecosystem is similar to that in different forest ecosystems.

Effect of $\mathrm{N}$ addition on methanogen abundance, diversity, and community structure. $\mathrm{N}$ addition significantly increased the abundance of the $m c r A$ gene but decreased methanogen diversity, which partly supports the second hypothesis. Aronson et al. ${ }^{15}$ observed that the abundance of the $m c r A$ gene is greater with $\mathrm{N}$ treatments than with control treatment in a pine forest soil. High $\mathrm{N}$ concentrations stimulate multiple microbial processes and provide more substrate for methanogens compared with low $\mathrm{N}$ concentrations ${ }^{53}$. DOC could partly act as the substrate and affect soil microbial activity ${ }^{83}$. In this study, $\mathrm{N}$ addition (N30 treatment) promoted an increase in the DOC concentration, which could explain the increase in methanogen abundance under conditions of $\mathrm{N}$ addition. Furthermore, our previous studies found that $\mathrm{N}$ addition increases the leaf photosynthetic rate $^{84}$, soil $\mathrm{MBC}^{66}$, soil respiration rate ${ }^{23}$, and the decomposition rates of both leaf litter ${ }^{47}$ and fine roots ${ }^{65}$, which indirectly supports the aforementioned conclusion. Our study also found that the soil SOC and TN concentrations were lower in the $\mathrm{N}$ addition treatments than in the control treatment and were negatively correlated with methanogen abundance, which partly supports the idea that $\mathrm{N}$ addition significantly increases $m c r A$ gene abundance. Moreover, the Shannon and Chaol indexes for methanogens sharply declined with decreasing soil $\mathrm{pH}$ (from pH 4.9 to 4.2 ) in the $\mathrm{N}$ addition treatments, which is likely owing, in part, to a small fraction of methanogens not being able to survive in low-pH soil. For example, the relative abundance of Methanoculleus was lower in the $\mathrm{N}$ addition treatments and was positively correlated with both the $\mathrm{pH}$ and the Chao 1 and Shannon indexes for methanogens (Fig. 2). This result supports the conclusion that low $\mathrm{pH}$ resulted in a decrease in the relative abundance of some methanogens.

Methanogen community structure, like that of the methanotrophs, was influenced by $\mathrm{N}$ addition, which supports the second hypothesis of this study. Moreover, our results showed that soil pH was strongly correlated with methanogen community structure in Moso bamboo forest soils $(P<0.01)$. Some studies have found similar results $^{68,70}$. For example, Lin et al. ${ }^{68}$ found that $\mathrm{pH}$ strongly controls microbial community structure in soils with $\mathrm{N}$ fertilization treatments. This result was attributed to most microbes having relatively narrow pH optima ${ }^{69}$. Our results also showed that soil $\mathrm{pH}$ was significantly and positively correlated with the relative abundance of Methanoculleus but negatively correlated with the amount of $m c r A$ (Fig. 2), which supports the conclusion that soil $\mathrm{pH}$ plays a dominant role in determining the structure of methanogen communities. However, other soil physicochemical factors may also play important roles in determining soil microbial community patterns and cannot be ruled out. The soil $\mathrm{C} / \mathrm{N}$ ratio also significantly influenced the methanogen community structure, which is consistent with the results of Wan et al ${ }^{85}$, who found that the soil $\mathrm{C} / \mathrm{N}$ ratio is the major determining factor of the structure of microbial communities in subtropical coniferous and broadleaf forest plantation soils. The soil $\mathrm{C} / \mathrm{N}$ ratio can reflect the quality of the substrate for soil microorganism growth ${ }^{85}$. In general, microbial biomass and activity are constrained by the availability and quality of $\mathrm{C}$ and nutrients, which may shift the structure of microbial communities ${ }^{86}$. In fact, a few studies on methanogens have been performed in forest soils within the context of atmospheric $\mathrm{N}$ deposition ${ }^{15,35}$. Aronson et al. ${ }^{15}$ found that $\mathrm{N}$ addition increases methanogen abundance in the poorly drained pine forest soil but does not impact methanogen abundance in a well-drained site. In our study, we showed that $\mathrm{N}$ addition significantly influenced methanogen abundance, diversity, and community structure in Moso bamboo forest soils. The differences in these results may be attributed to the evaluation of different forest soil types, drainage conditions, and $\mathrm{N}$ addition rates. As such, it is important to study the effects of $\mathrm{N}$ addition on methanogens in a variety of forest soils.

Effect of $\mathbf{N}$ addition on $\mathrm{CH}_{4}$ flux. The oxidation of $\mathrm{CH}_{4}$ from the atmosphere is an important function in forest ecosystems ${ }^{5}$. Our results indicate that $\mathrm{N}$ addition significantly decreased $\mathrm{CH}_{4}$ uptake in the Moso bamboo forest, which supports the third hypothesis of this study and is consistent with the results of previous studies that have shown a negative effect of $\mathrm{N}$ addition on $\mathrm{CH}_{4}$ oxidation in forest soils ${ }^{18,87}$. Mo et al. ${ }^{48}$ and $\mathrm{Zhang}$ et al. ${ }^{49}$ also observed that $\mathrm{CH}_{4}$ uptake in monsoon evergreen broadleaf forest soils is significantly reduced by $\mathrm{N}$ deposition in southern China. The decrease in $\mathrm{CH}_{4}$ uptake with $\mathrm{N}$ addition is probably owing to increased methanogen 
and decreased methanotroph abundances ${ }^{7}$. It has been found that the abundance of USC- $\alpha$ is positively correlated with $\mathrm{CH}_{4}$ uptake in forest soils ${ }^{38}$. Aronson and Helliker ${ }^{87}$ found that large amounts of available $\mathrm{N}$ inhibit methanotrophs in non-wetland soil systems. Similarly, we found that $\mathrm{N}$ addition decreased methanotroph diversity and altered the community structure of methanotrophs. Pearson's correlation analysis demonstrated that methanotroph diversity (Shannon and Chaol indexes) was strongly correlated with $\mathrm{CH}_{4}$ flux, which agrees with the findings of Schnyder et al..$^{32}$, who deduced that the diversity of methanotrophic communities is important for $\mathrm{CH}_{4}$ oxidation. The result also provides direct evidence for the loss of microbial diversity with increasing $\mathrm{N}$ deposition rates, which results in altered ecosystem functions. Moreover, Shang et al. ${ }^{29}$ showed that methanogen activity is enhanced by $\mathrm{N}$ addition, which results in the production of more $\mathrm{CH}_{4}$. In our study, $\mathrm{N}$ addition significantly increased methanogen abundance, which was positively correlated with $\mathrm{CH}_{4}$ flux. Our results indicate that $\mathrm{N}$ deposition resulted in the suppression of $\mathrm{CH}_{4}$ uptake in Moso bamboo forest soils, thereby contributing to an increased concentration of atmospheric $\mathrm{CH}_{4}$. In addition, abiotic soil factors, such as $\mathrm{pH}$, directly and indirectly influence $\mathrm{CH}_{4}$ flux ${ }^{88}$ by altering methanotroph and methanogen abundance, diversity, and community structure.

\section{Conclusions}

The present study provides evidence that $\mathrm{N}$ deposition may influence methanotroph and methanogen abundance, diversity, and community structure by decreasing $\mathrm{pH}$ in Moso bamboo forest soil. Furthermore, $\mathrm{N}$ addition significantly decreased methanotroph and methanogen diversity, which may influence their ecosystem functions, such as $\mathrm{CH}_{4}$ uptake. Increasing the soil $\mathrm{pH}$ should be an effective intervention option to alleviate the effect of $\mathrm{N}$ deposition on methanotrophs and methanogens. In this study, we ignored the potential role of anaerobic methanotrophs and soil characteristics (horizon layering, hydrology, and oxygen availability) over soil depths. In a further study, we will investigate the effect of $\mathrm{N}$ addition on soil anaerobic methanotrophs and soil characteristics of different depths in the Moso bamboo plantation. Besides, the long-term effect of $\mathrm{N}$ deposition on methanotrophs and methanogens, the $\mathrm{CH}_{4}$ emission rate, and the associated underlying mechanisms should be evaluated in future studies.

\section{Materials and methods}

Experimental site and design. The field site was established in Qingshan Town, Hangzhou City $\left(30^{\circ} 14^{\prime}\right.$ $\mathrm{N}, 119^{\circ} 42^{\prime} \mathrm{E}$ ), Zhejiang Province, China. The soil type is classified as a ferrosol derived from granite ${ }^{23,50}$. Moso bamboo is an economically important bamboo species in Southeast China and the most important source of non-wood forest products in China ${ }^{47}$. The Moso bamboo forest at the study site was originally established in the late 1970s from a native evergreen broadleaf forest in sites of similar topography ${ }^{65}$. The Moso bamboo forest, with 11 understory herbal species, achieves a mean height of $0.1 \mathrm{~m}$. Forest floor coverage is $5 \%$ with a total herbal biomass of $14.6 \mathrm{~kg} \mathrm{ha}^{-1}$. The forest is influenced by a subtropical monsoon climate, with a mean annual temperature of $15.6^{\circ} \mathrm{C}$ and mean annual precipitation of $1420 \mathrm{~mm}$. The initial soil characteristics are summarized in Table $\mathrm{S} 2$.

Twelve ( 3 replicates per treatment $\times 4$ treatments) randomly scattered plots $(20 \mathrm{~m} \times 20 \mathrm{~m}$ per plot) were established in November 2012. Adjacent plots were separated by a $20-\mathrm{m}$ buffer zone. Four distinct $\mathrm{N}$ treatments were defined: Control $\left(0 \mathrm{~kg} \mathrm{~N} \mathrm{ha}^{-1} \mathrm{yr}^{-1}\right), \mathrm{N} 30\left(30 \mathrm{~kg} \mathrm{~N} \mathrm{ha}^{-1} \mathrm{yr}^{-1}\right), \mathrm{N} 60\left(60 \mathrm{~kg} \mathrm{~N} \mathrm{ha}^{-1} \mathrm{yr}^{-1}\right)$, and N90 $\left(90 \mathrm{~kg} \mathrm{~N} \mathrm{ha}^{-1} \mathrm{yr}^{-1}\right)$. The $\mathrm{N}$-addition treatments were designed to simulate single (N30), double (N60), or triple (N90) ambient $\mathrm{N}$ deposition rates $\left(30 \mathrm{~kg} \mathrm{~N} \mathrm{ha}^{-1} \mathrm{yr}^{-1}\right)$ in the region ${ }^{46}$. $\mathrm{NH}_{4} \mathrm{NO}_{3}$ was used to simulate $\mathrm{N}$ deposition given that the $\mathrm{N}$ that is typically deposited through natural and anthropogenic processes is mainly in the form of $\mathrm{NH}_{4}{ }^{+}$and $\mathrm{NO}_{3}{ }^{-89,90}$, which account for $56.1 \%$ and $43.9 \%$ of wet $\mathrm{N}$ deposition in China, respectively ${ }^{91}$. Different concentrations of $\mathrm{NH}_{4} \mathrm{NO}_{3}$ solution (mixed with $10 \mathrm{~L}$ of water) were sprayed over the plots each month starting from January 2013 to March 2018. Each control plot received $10 \mathrm{~L}$ of water.

Soil sampling and physicochemical analysis. For each plot, bulk soil $(0-20 \mathrm{~cm}$ depth) was collected in early March 2018 from ten randomly selected points and mixed to form one composite sample. The samples were transported to the laboratory in a constant temperature box $\left(4{ }^{\circ} \mathrm{C}\right)$ containing ice within hours of being collected. After visible stones, roots, and litter were removed using forceps, the soil samples were gently broken apart along natural-break points and thoroughly mixed. One portion of the soil sample was passed through a 2.0-mm sieve and stored at $-80^{\circ} \mathrm{C}$ for subsequent DNA extraction, quantitative PCR, and high-throughput sequencing. Another portion of the soil was passed through a $2.0-\mathrm{mm}$ sieve and subsequently divided into two parts for soil physicochemical property analysis. A part of each fresh sample was stored at $4{ }^{\circ} \mathrm{C}$ for the analysis of MBC, DOC, inorganic $\mathrm{N}\left(\mathrm{NH}_{4}{ }^{+}\right.$and $\left.\mathrm{NO}_{3}{ }^{-}\right)$, and soil moisture. $\mathrm{MBC}$ was estimated using the chloroform fumigation-extraction method ${ }^{92,93}$. DOC was extracted with distilled water, passed through a $0.45-\mathrm{mm}$ filter, and evaluated using a TOC analyzer (TOC-VCHP, Shimadzu, Kyoto, Japan). $\mathrm{NH}_{4}{ }^{+}$and $\mathrm{NO}_{3}{ }^{-}$were extracted with $2 \mathrm{M} \mathrm{KCl}$ and measured using a SmartChem 200 Discrete Analyzer (Alliance Instruments, Frepillon, France). Fresh soil samples were weighed and then dried in an oven at $105^{\circ} \mathrm{C}$ to a constant weight to determine gravimetric soil moisture ${ }^{94}$. The other parts were air-dried and stored at room temperature $\left(25^{\circ} \mathrm{C}\right)$. Air-died soils were used to determine soil $\mathrm{pH}, \mathrm{SOC}, \mathrm{TN}$, and AP. Soil $\mathrm{pH}$ was measured using a pH meter (FE20, Mettler-Toledo, Zurich, Switzerland) after a soil-water (1:2.5 dry w/v) mixture was created and shaken for $30 \mathrm{~min}$. SOC and TN concentrations were measured using a Vario Max element analyzer (Elementar, Hanau, Germany). AP was extracted with $0.0125 \mathrm{M} \mathrm{H}_{2} \mathrm{SO}_{4}$ in $0.05 \mathrm{M} \mathrm{HCl}$ and its concentration was determined using the molybdenum blue method ${ }^{84}$. 
DNA extraction and quantitative PCR. Soil DNA was extracted from $0.3 \mathrm{~g}$ of soil after sampling using the Ezup Column Soil DNA Purification Kit (Sangon Biotech, Shanghai, China) according to the manufacturer's protocol. The quality and concentration of the extracted DNA were evaluated by gel electrophoresis $(0.8 \%$ agarose) and a NanoDrop spectrophotometer (NanoDrop Technologies, Wilmington, DE, USA), and the extracted DNA was subsequently stored at $-20^{\circ} \mathrm{C}$.

The primers A189f. (5'-GGNGACTGGGACTTCTGG-3') and 650R (5'-ACGTCCTTACCGAAGGT-3' $)^{95}$ and mlas-mod-F (5'-GGYGGTGTMGGDTTCACMCARTA-3') and mcrA-rev-R (5'-CGTTCATBGCGTAG TTVGGRTAGT- $\left.3^{\prime}\right)^{96}$ were used for $p m o A$ and $m c r A$ gene amplification, respectively. Functional methanotroph and methanogen genes were quantified using qPCR in a CFX connect Real-Time Detection System (Bio-Rad Laboratories Inc., Hercules, CA, USA). The DNA sample was used for qPCR after a tenfold dilution. There was a single dissolution curve peak. The qPCR reaction mixture contained $10 \mu \mathrm{L}$ of $2 \times$ ChamQ SYBR Color qPCR Master Mix, $2 \mu \mathrm{L}$ of each primer $(10 \mu \mathrm{M}), 1 \mu \mathrm{L}$ of DNA template (1-10 ng), and $7 \mu \mathrm{L}$ of $\mathrm{ddH}_{2} \mathrm{O}$. Amplification was initiated by denaturation at $95^{\circ} \mathrm{C}$ for $3 \mathrm{~min}$, followed by 35 cycles of denaturation at $95^{\circ} \mathrm{C}$ for $20 \mathrm{~s}$, annealing at $60{ }^{\circ} \mathrm{C}$ for $30 \mathrm{~s}$, and extension at $72^{\circ} \mathrm{C}$ for $20 \mathrm{~s}$, and the plate was read at $80^{\circ} \mathrm{C}$. To generate a standard curve, individual clones with accurate inserts were cultured in Luria-Bertani medium and the plasmid DNA was extracted, purified, and quantified. Plasmid DNA was prepared in a tenfold dilution series to yield a standard curve covering six orders of magnitude $\left(10^{2}\right.$ to $10^{8}$ copies) per assay ${ }^{35}$. The qPCR assay was performed in triplicate for each replicate. The qPCR amplification average efficiencies were $97 \%$ and the $\mathrm{R}^{2}$ was 0.996 .

High-throughput sequencing and bioinformatics. PCR amplification was performed for each soil DNA extract, using the above-mentioned primers (A189f. and 650R and mlas-mod-F and mcrA-rev-R), in triplicate and combined into a single composite sample. This is because these primers are widely used to study upland soils and cover the most methanotrophs and methanogens ${ }^{35,38,95,96}$. The specificity of the primer, which had been checked by Primer-BLAST, was good. The amplicon size of $p m o A$ and $m c r A$ was 500 and 469 bp, respectively. The PCR products were subsequently purified with AMPure XT beads (Beckman Coulter Genomics, Danvers, MA, USA) and quantified by Qubit (Invitrogen Corporation, Carlsbad, CA, USA). The PCR amplicon pools were prepared for sequencing and library quality was assessed using an Agilent 2100 Bioanalyzer (Agilent, Palo Alto, CA, USA) and the Library Quantification Kit for Illumina (Kapa Biosciences, Woburn, MA, USA). Finally, high-throughput sequencing for $p m o A / m c r A$ genes was carried out using a $2 \times 300$ bp paired-end Illumina MiSeq PE300 at LC-Bio Technology Co., Ltd, Hang Zhou, Zhejiang Province, China.

The obtained sequencing data were processed using the Quantitative Insights into Microbial Ecology (QIIME) pipeline ${ }^{97}$. Sequence data, including raw data and clean data, were filtered using Mothur. The proportion of chimeric sequences of $p m o A$ and $m c r A$ was $4.8 \%$ and $6.5 \%$. The non-chimeric $p m o A$ and $m c r A$ gene reads were then checked for frameshift errors using the "FrameBot" tool ${ }^{98-100}$. The above analysis resulted in a total of 424,628 (ranging from 31,030 to 40,328 sequences per sample) and 775,842 (ranging from 36,438 to 40,328 sequences per sample) high-quality sequences of $p m o A$ and $m c r A$ in all samples, respectively (Table S3). To standardize the results, we resampled each sample using the sequence number of the sample with the least sequences and calculated the diversity indices based on this normalized data set ${ }^{101,102}$. The remaining high-quality sequences were clustered into OTUs at a $97 \%$ identity threshold using UCLUST. The taxonomic information of each OTU was annotated using the taxonomically determined reference sequences from the National Center for Biotechnology Information (NCBI v20180310) using BLAST ${ }^{35,38,39}$. The specific parameter settings of BLAST were as follows: the minimum identity was $70 \%$, the minimum query coverage was $70 \%$, the maximum E-value was $10^{-5}$, and the E-value interval multiple was 10 times. The detailed parameters and classification methods have been described by Liu et al. ${ }^{35}$. Alpha diversity was assessed by calculating the Chao ${ }^{63}$ and Shannon ${ }^{64}$ indexes in QIIME (Version 1.8.0). Furthermore, QIIME was used to calculate the weighted UniFrac, and unweighted pair group method with arithmetic mean clustering was conducted on the weighted UniFrac based on a previously published protocol ${ }^{66}$. All sequence data in this study are deposited in the Sequence Read Achieve database of NCBI under accession number SRP255341.

$\mathrm{CH}_{4}$ measurement. $\mathrm{CH}_{4}$ samples were collected once each month on a clear day using a widely applicable static chamber and measured using gas chromatography techniques ${ }^{103}$. The sampling process has been described in a previous study ${ }^{23}$. In brief, the static chambers were made of opaque polyvinyl chloride panels, including a square base box $(40 \times 40 \times 10 \mathrm{~cm})$ and a $U$-shaped groove $(50 \mathrm{~mm}$ wide and $50 \mathrm{~mm}$ deep) at the top edges that held a removable top $(40 \times 40 \times 40 \mathrm{~cm})$. In each plot, three boxes were installed $10 \mathrm{~cm}$ below the soil surface. The chamber tops were placed onto the base boxes during gas sampling, and the grooves were filled with water to act as an air seal. A small fan was installed inside the top of each chamber to generate turbulence during sampling. Sampling was conducted between 9:00 am and 11:00 am to minimize the influence of diurnal variation. Gas samples $(60 \mathrm{~mL})$ were extracted from the chamber at $0,10,20$, and $30 \mathrm{~min}$ using polyurethane syringes and stored in gas sampling bags (Delin Ltd., Dalian, China). The $\mathrm{CH}_{4}$ concentrations were determined using a gas chromatograph (GC-2014; Shimadzu Corporation, Kyoto, Japan) within 1 day of sample collection. The $\mathrm{CH}_{4}$ flux was calculated using the following formula ${ }^{103}$ :

$$
F=\left(\frac{d c}{d t}\right) \times\left(\frac{M}{V_{0}}\right) \times\left(\frac{273.15}{T}\right) \times\left(\frac{V}{A}\right)
$$

where $F\left(\mathrm{mg} \mathrm{m}^{-2} \mathrm{~h}^{-1}\right)$ is the soil $\mathrm{CH}_{4}$ flux; $\frac{d c}{d t}$ is the slope of the linear regression between the change in the $\mathrm{CH}_{4}$ concentration $(d c)$ and the time $(d t)$ in the chamber; $M$ and $V_{0}$ are the molar mass and molar volume of $\mathrm{CH}_{4}$ under standard conditions, respectively; $\mathrm{T}$ is the absolute air temperature during sampling; and $\mathrm{V}\left(\mathrm{m}^{3}\right)$ and $\mathrm{A}$ 
$\left(\mathrm{m}^{2}\right)$ are the effective volume and bottom area of the chamber, respectively. Owing to the malfunction of the gas chromatograph in March 2018, the data of $\mathrm{CH}_{4}$ flux for that month were abnormal and, thus, were eliminated. The $\mathrm{CH}_{4}$ flux data collected in late February 2018, 12 days before the soil sampling in March, were used to analyze the correlation between $\mathrm{CH}_{4}$ flux and the abundance, diversity, and community structures of methanotrophs and methanogens in the present study.

Statistical analysis. A one-way analysis of variance (ANOVA) was performed to assess the differences in the number of gene copies, Chaol index, Shannon index, and $\mathrm{CH}_{4}$ flux among the different treatments. Posthoc multiple comparisons were conducted using the least significant difference (LSD) method. All data were tested for homogeneity of variance and normality of distribution prior to conducting the ANOVA. The relative abundance of the major genera was analyzed using STAMP software (v2.1.3) with a correction for multiple comparisons using the Bonferroni method. Pearson's correlation analysis was used to test the association among soil physicochemical variables, alpha diversity, the relative abundance of the major genera, and $\mathrm{CH}_{4}$ flux, across all treatments. All these analyses were performed using SPSS v. 18.0 (SPSS Inc., Chicago, IL, USA).

$\mathrm{R}$ software (Version 3.4.1) was utilized to conduct the following analyses. First, correlations between soil physicochemical variables and OTUs were calculated with the vegan package using a Monte Carlo permutation test, canonical correspondence analysis (CCA), and analysis of similarities (ANOSIM). Venn diagrams for graphical descriptions of unique and shared OTUs between different ecosystems were generated using the VennDiagram package.

Received: 30 July 2020; Accepted: 11 February 2021

Published online: 10 March 2021

\section{References}

1. Ni, X. \& Groffman, P. M. Declines in methane uptake in forest soils. Proc. Natl. Acad. Sci. USA 115, 8587-8590 (2018).

2. IPCC. Climate change 2013: the physical science basis Contribution of Working Group I to the Fifth Assessment Report of the Intergovernmental Panel on Climate Change (Cambridge University Press, 2013).

3. Kirschke, S. et al. Three decades of global methane sources and sinks. Nat. Geosci. 6, 813-823 (2013).

4. Turner, A. J., Frankenberg, C. \& Kort, E. A. Interpreting contemporary trends in atmospheric methane. Proc. Natl. Acad. Sci. USA 116, 2805-2813 (2019).

5. Tate, K. R. Soil methane oxidation and land-use change-from process to mitigation. Soil Biol. Biochem. 80, 260-272 (2015).

6. Thauer, R. K., Anne-Kristin, K., Henning, S., Wolfgang, B. \& Reiner, H. Methanogenic archaea: ecologically relevant differences in energy conservation. Nat. Rev. Microbiol. 6, 579-591 (2008).

7. Banger, K., Tian, H. \& Lu, C. Do nitrogen fertilizers stimulate or inhibit methane emissions from rice fields?. Glob. Change Biol. 18, 3259-3267 (2012).

8. Murase, J. \& Kimura, M. Methane production and its fate in paddy fields. IV. Sources of microorganisms and substrates responsible for anaerobic $\mathrm{CH}_{4}$ oxidation in subsoil. Soil Sci. Plant Nutr. 40, 57-61 (1994).

9. Zhang, M., Huang, J., Sun, S., Rehman, M. \& He, S. Depth-specific distribution and significance of nitrite-dependent anaerobic methane oxidation process in tidal flow constructed wetlands used for treating river water. Sci. Total Environ. 716, 107354 (2020).

10. Yu, X. et al. Sonneratia apetala introduction alters methane cycling microbial communities and increases methane emissions in mangrove ecosystems. Soil Biol. Biochem. 144, 107775 (2020).

11. Hanson, R. S. \& Hanson, T. E. Methanotrophic bacteria. Microbiol. Rev. 60, 439-471 (1996).

12. Knief, C. Diversity and habitat preferences of cultivated and uncultivated aerobic methanotrophic bacteria evaluated based on pmoA as molecular marker. Front. Microbiol. 6, 1346 (2015).

13. Dunfield, P., Knowles, R., Dumont, R. \& Moore, T. R. Methane production and consumption in temperate and subarctic peat soils: response to temperature and pH. Soil Biol. Biochem. 25, 321-326 (1993).

14. Mer, J. L. \& Roger, P. Production, oxidation, emission and consumption of methane by soils: a review. Eur. J. Soil Biol. 37, 25-50 (2001).

15. Aronson, E. L., Dubinsky, E. A. \& Helliker, B. R. Effects of nitrogen addition on soil microbial diversity and methane cycling capacity depend on drainage conditions in a pine forest soil. Soil Biol. Biochem. 62, 119-128 (2013).

16. Bodelier, P. L. E. \& Laanbroek, H. J. Nitrogen as a regulatory factor of methane oxidation in soils and sediments. FEMS Microbiol. Ecol. 47, 265-277 (2004).

17. Galloway, J. N. et al. Transformation of the nitrogen cycle: recent trends, questions, and potential solutions. Science 320, 889-892 (2008).

18. Liu, L. \& Greaver, T. L. A review of nitrogen enrichment effects on three biogenic GHGs: the $\mathrm{CO}_{2}$ sink may be largely offset by stimulated $\mathrm{N}_{2} \mathrm{O}$ and $\mathrm{CH}_{4}$ emission. Ecol. Lett. 12, 1103-1117 (2009).

19. Fowler, D., Coyle, M., Skiba, U., Sutton, M. A. \& Voss, M. The global nitrogen cycle in the twenty-first century. Philos. Trans. R. Soc. B. 368, 20130164 (2013).

20. Reay, D. S., Dentener, F., Smith, P., Grace, J. \& Feely, R. A. Global nitrogen deposition and carbon sinks. Nat. Geosci. 1, 430-437 (2008).

21. Ackerman, D., Millet, D. B. \& Chen, X. Global estimates of inorganic nitrogen deposition across four decades. Glob. Biogeochem. Cycles 33, 100-107 (2019).

22. Liu, X. et al. Enhanced nitrogen deposition over China. Nature 494, 459-462 (2013).

23. Li, Q. et al. Nitrogen depositions increase soil respiration and decrease temperature sensitivity in a Moso bamboo forest. Agric. For. Meteorol. 268, 48-54 (2019).

24. Steudler, P. A., Bowden, R. D., Melillo, J. M. \& Aber, J. D. Influence of nitrogen fertilization on methane uptake in temperate forest soils. Nature 341, 314-316 (1989).

25. Hütsch, B. W., Webster, C. P. \& Powlson, D. S. Methane oxidation in soil as affected by land use, soil pH and N fertilization. Soil Biol. Biochem. 26, 1613-1622 (1994).

26. Bodelier, P. L. E., Roslev, P., Henckel, T. \& Frenzel, P. Stimulation by ammonium-based fertilizers of methane oxidation in soil around rice roots. Nature 403, 421-424 (2000).

27. Kruger, M. \& Frenzel, P. Effects of $\mathrm{N}$-fertilisation on $\mathrm{CH}_{4}$ oxidation and production, and consequences for $\mathrm{CH}_{4}$ emissions from microcosms and rice fields. Glob. Change Biol. 9, 773-784 (2003).

28. Delgado, J. A. \& Mosier, A. R. Mitigation alternatives to decrease nitrous oxides emissions and urea-nitrogen loss and their effect on methane flux. J. Environ. Qual. 25, 1105-1111 (1996). 
29. Shang, Q. et al. Net annual global warming potential and greenhouse gas intensity in Chinese double rice-cropping systems: a 3-year field measurement in long-term fertilizer experiments. Glob. Change Biol. 17, 2196-2210 (2011).

30. Cai, Z. et al. Methane and nitrous oxide emissions from rice paddy fields as affected by nitrogen fertilizers and water management. Plant Soil 196, 7-14 (1997).

31. Malghani, S., Reim, A., Fischer, J. V., Conrad, R. \& Trumbore, S. E. Soil methanotroph abundance and community composition are not influenced by substrate availability in laboratory incubations. Soil Biol. Biochem. 101, 184-194 (2016).

32. Schnyder, E., Bodelier, P. L. E., Hartmann, M., Henneberger, R. \& Niklaus, P. A. Positive diversity-functioning relationships in model communities of methanotrophic bacteria. Ecology 99, 714-723 (2018).

33. Wang, C., Liu, D. \& Bai, E. Decreasing soil microbial diversity is associated with decreasing microbial biomass under nitrogen addition. Soil Biol. Biochem. 120, 126-133 (2018).

34. Shrestha, M., Shrestha, P. M., Frenzel, P. \& Conrad, R. Effect of nitrogen fertilization on methane oxidation, abundance, community structure, and gene expression of methanotrophs in the rice rhizosphere. ISME J. 4, 1545-1556 (2010).

35. Liu, H. et al. Responses of soil methanogens, methanotrophs, and methane fluxes to land-use conversion and fertilization in a hilly red soil region of southern China. Environ. Sci. Pollut. Res. 24, 8731-8743 (2017).

36. Bao, Q., Ding, L. J., Huang, Y. \& Xiao, K. Effect of rice straw and/or nitrogen fertiliser inputs on methanogenic archaeal and denitrifying communities in a typical rice paddy soil. Earth Environ. Sci. Trans. R. Soc. Edinb. 109, 375-386 (2019).

37. Ho, A. et al. The more, the merrier: heterotroph richness stimulates methanotrophic activity. ISME J. 8, 1945-1948 (2014).

38. Dan, H. et al. The response of methanotrophs to additions of either ammonium, nitrate or urea in alpine swamp meadow soil as revealed by stable isotope probing. FEMS Microbiol. Ecol. 7, fiz077 (2019).

39. Zhang, D., Mo, L., Chen, X., Zhang, L. \& Xu, X. Effect of nitrogen addition on methanotrophs in temperate forest soil. Acta Ecol. Sin. 37, 8254-8263 (2017)

40. Mohanty, S. R., Bodelier, P. L. E., Floris, V. \& Conrad, R. Differential effects of nitrogenous fertilizers on methane-consuming microbes in rice field and forest soils. Appl. Environ. Microbiol. 72, 1346-1354 (2006).

41. Hu, A. \& Lu, Y. The differential effects of ammonium and nitrate on methanotrophs in rice field soil. Soil Biol. Biochem. 85, 31-38 (2015).

42. Shrestha, P. M. et al. Linking activity, composition and seasonal dynamics of atmospheric methane oxidizers in a meadow soil. ISME J. 6, 1115-1126 (2012).

43. Jang, I., Lee, S., Zoh, K. D. \& Kang, H. Methane concentrations and methanotrophic community structure influence the response of soil methane oxidation to nitrogen content in a temperate forest. Soil Biol. Biochem. 43, 620-627 (2011).

44. Song, X., Chen, X., Zhou, G., Jiang, H. \& Peng, C. Observed high and persistent carbon uptake by Moso bamboo forests and its response to environmental drivers. Agric. For. Meteorol. 247, 467-475 (2017).

45. Song, X. et al. Carbon sequestration by Chinese bamboo forests, and their ecological benefits: assessment of potential, problems, and future challenges. Environ. Rev. 19, 418-428 (2011).

46. Jia, Y. et al. Spatial and decadal variations in inorganic nitrogen wet deposition in China induced by human activity. Sci. Rep. 4, 3763 (2014).

47. Song, X., Zhou, G., Gu, H. \& Qi, L. Management practices amplify the effects of N deposition on leaf litter decomposition of the Moso bamboo forest. Plant Soil 395, 391-400 (2015).

48. Mo, J., Fang, Y., Xu, G., Li, D. \& Xue, J. The short-term responses of soil $\mathrm{CO}_{2}$ emission and $\mathrm{CH}_{4}$ uptake to simulated $\mathrm{N}$ deposition in nursery and forests of Dinghushan in subtropical China. Acta Ecol. Sin. 25, 682-690 (2005).

49. Zhang, W. et al. Methane uptake responses to nitrogen deposition in three tropical forests in southern China. J. Geophys. Res. 113, D11116 (2008)

50. Song, X. et al. Nitrogen addition increased $\mathrm{CO}_{2}$ uptake more than non- $\mathrm{CO}_{2}$ greenhouse gases emissions in a Moso bamboo forest. Sci. Adv. 6, eaaw5790 (2020).

51. Knief, C., Lipski, A. \& Dunfield, P. F. Diversity and activity of methanotrophic bacteria in different upland soils. Appl. Environ. Microbiol. 69, 6703-6714 (2003).

52. Wang, M., Xu, X., Wang, W., Wang, G. \& Su, C. Effects of slag and biochar amendments on methanogenic community structures in paddy fields. Acta Ecol. Sin. 38, 2816-2818 (2018).

53. Zeikus, J. G. Biology of methanogenic bacteria. Bacteriol. Rev. 41, 514-541 (1977).

54. Täumer, J. et al. Divergent drivers of the microbial methane sink in temperate forest and grassland soils. Glob. Change Biol. 27, 929-940 (2021).

55. Pratscher, J., Vollmers, J., Wiegand, S., Dumont, M. G. \& Kaster, A. K. Unravelling the identity, metabolic potential and global biogeography of the atmospheric methane-oxidizing upland soil cluster a. Environ. Microbiol. 20(3), 1016-1029 (2018).

56. Knief, C. Diversity and habitat preferences of cultivated and uncultivated aerobic methanotrophic bacteria evaluated based on pmoA as molecular marker. Front. Microbiol. 6, 487 (2015).

57. Deng, Y. et al. Upland soil cluster gamma dominates methanotrophic communities in upland grassland soils. Sci. Total Environ. 670, 826-836 (2019).

58. Henckel, T., Friedrich, M. \& Conrad, R. Molecular analyses of the methane-oxidizing microbial community in rice field soil by targeting the genes of the $16 \mathrm{~S}$ rRNA, particulate methane monooxygenase, and methanol dehydrogenase. Appl. Environ. Microbiol. 65, 1980-1990 (1999).

59. Lieberman, R. L. \& Rosenzweig, A. C. Biological methane oxidation: regulation, biochemistry, and active site structure of particulate methane monooxygenase. Crit. Rev. Biochem. Mol. Biol. 39, 147-164 (2004).

60. Freitag, T. E. \& Prosser, J. I. Correlation of methane production and functional gene transcriptional activity in a peat soil. Appl. Environ. Microbiol. 75, 6679-6687 (2009).

61. Thauer, R. K. Biochemistry of methanogenesis: a tribute to Marjory Stephenson: 1998 Marjory Stephenson prize lecture. Microbiology 144, 2377-2406 (1998).

62. Schnell, S. \& King, G. M. Mechanistic analysis of ammonium inhibition of atmospheric methane consumption in forest soils. Appl. Environ. Microbiol. 60, 3514-3521 (1994).

63. Chao, A. Nonparametric estimation of the number of classes in a population. Scand. J. Stat. 11, 265-270 (1984).

64. Shannon, C. E. A. mathematical theory of communication. Bell Syst. Tech. J. 27, 379-423 (1948).

65. Li, Q. et al. Biochar amendment decreases soil microbial biomass and increases bacterial diversity in Moso bamboo (Phyllostachys edulis) plantations under simulated nitrogen deposition. Environ. Res. Lett. 13, 044029 (2018).

66. Li, Q., Song, X., Gu, H. \& Gao, F. Nitrogen deposition and management practices increase soil microbial biomass carbon but decrease diversity in Moso bamboo plantations. Sci. Rep. 6, 28235 (2016).

67. Frey, S. D., Knorr, M., Parrent, J. L. \& Simpson, R. T. Chronic nitrogen enrichment affects the structure and function of the soil microbial community in temperate hardwood and pine forests. For. Ecol. Manag. 196, 159-171 (2004).

68. Lin, Y. et al. Long-term application of lime or pig manure rather than plant residues suppressed diazotroph abundance and diversity and altered community structure in an acidic ultisol. Soil Biol. Biochem. 123, 218-228 (2018).

69. Rousk, J. et al. Soil bacterial and fungal communities across a pH gradient in an arable soil. ISME J. 4, 1340-1351 (2010).

70. Zhou, X., Guo, Z., Chen, C. \& Jia, Z. Soil microbial community structure and diversity are largely influenced by soil pH and nutrient quality in 78-year-old tree plantations. Biogeosciences 14, 2101-2111 (2017). 
71. Nicol, G. W., Leininger, S., Schleper, C. \& Prosser, J. I. The influence of soil pH on the diversity, abundance and transcriptional activity of ammonia oxidizing archaea and bacteria. Environ. Microbiol. 10, 2966-2978 (2008).

72. Vitousek, P. M. et al. Technical report: human alteration of the global nitrogen cycle: sources and consequences. Ecol. Appl. 7, 737 (1997).

73. Treseder, K. K. Nitrogen additions and microbial biomass: a meta-analysis of ecosystem studies. Ecol. Lett. 11, 1111-1120 (2008).

74. Serna-Chavez, H. M. \& Bodegom, P. M. V. Global drivers and patterns of microbial abundance in soil. Glob. Ecol. Biogeogr. 22, $1162-1172(2013)$

75. Rosso, L., Lobry, J. R., Bajard, S. \& Flandrois, J. P. Convenient model to describe the combined effects of temperature and $\mathrm{pH}$ on microbial growth. Appl. Environ. Microbiol. 61, 610-616 (1995).

76. Högberg, M. N., Högberg, P. \& Myrold, D. D. Is microbial community composition in boreal forest soils determined by pH, C-to-N ratio, the trees, or all three?. Oecologia 150, 590-601 (2007).

77. Sterner, R. W. \& Elser, J. J. Ecological Stoichiometry: The Biology of Elements from Molecules to the Biosphere (Princeton University Press, Princeton, 2002).

78. Kolb, S. The quest for atmospheric methane oxidizers in forest soils. Environ. Microbiol. Rep. 1, 336-346 (2009).

79. Topp, E. \& Pettey, E. Soils as sources and sinks for atmospheric methane. Can. J. Soil Sci. 77, 167-177 (1997).

80. Bender, M. \& Conrad, R. Effect of $\mathrm{CH}_{4}$ concentrations and soil conditions on the induction of $\mathrm{CH}_{4}$ oxidation activity. Soil Biol. Biochem. 27, 1517-1527 (1995).

81. Kolb, S., Knief, C., Dunfield, P. F. \& Conrad, R. Abundance and activity of uncultured methanotrophic bacteria involved in the consumption of atmospheric methane in two forest soils. Environ. Microbiol. 7(8), 1150-1161 (2005).

82. Degelmann, D. M., Borken, W., Drake, H. L. \& Kolb, S. Different atmospheric methane-oxidizing communities in European Beech and Norway Spruce Soils. Appl. Environ. Microbiol. 76(10), 3228-3235 (2010).

83. Li, S., Yu, Y. \& He, S. Summary of research on dissolved organic carbon (DOC). Soil Environ. Sci. 11, 422-429 (2002).

84. Zhang, R. et al. Nitrogen deposition enhances photosynthesis in Moso bamboo but increases susceptibility to other stress factors. Front. Plant Sci. 8, 1975 (2017).

85. Wan, X. et al. Soil C:N ratio is the major determinant of soil microbial community structure in subtropical coniferous and broadleaf forest plantations. Plant Soil 387, 103-116 (2015).

86. Demoling, F., Figueroa, D. \& Bååth, E. Comparison of factors limiting bacterial growth in different soils. Soil Biol. Biochem. 39, 485-2495 (2007).

87. Aronson, E. L. \& Helliker, B. R. Methane flux in non-wetland soils in response to nitrogen addition: a meta-analysis. Ecology 91, 3242-3251 (2010).

88. Cheng, S. et al. The primary factors controlling methane uptake from forest soils and their responses to increased atmospheric nitrogen deposition: a review. Acta Ecol. Sin. 32, 4914-4923 (2012).

89. Fierer, N. et al. Comparative metagenomic, phylogenetic and physiological analyses of soil microbial communities across nitrogen gradients. ISME J. 6, 1007-1017 (2012).

90. Ramirez, K. S., Craine, J. M. \& Fierer, N. Consistent effects of nitrogen amendments on soil microbial communities and processes across biomes. Glob. Change Biol. 18, 1918-1927 (2012).

91. Song, X., Li, Q. \& Gu, H. Effect of nitrogen deposition and management practices on fine root decomposition in Moso bamboo plantations. Plant Soil 410, 207-215 (2017).

92. Vance, E. D., Brookes, P. C. \& Jenkinson, D. S. An extraction method for measuring soil microbial biomass C. Soil Biol. Biochem. 19, 703-707 (1987).

93. Li, Y. et al. Biochar reduces soil heterotrophic respiration in a subtropical plantation through increasing soil organic carbon recalcitrancy and decreasing carbon-degrading microbial activity. Soil Biol. Biochem. 122, 173-185 (2018).

94. Lu, R. Methods for Soil Agro-chemistry Analysis (China Agricultural Science and Technology Press, Beijing, 2000).

95. Bourne, D. G., Mcdonald, I. R. \& Murrell, J. C. Comparison of pmoA PCR primer sets as tools for investigating methanotroph diversity in three Danish soils. Appl. Environ. Microbiol. 67, 3802 (2001).

96. Angel, R., Claus, P. \& Conrad, R. Methanogenic archaea are globally ubiquitous in aerated soils and become active under wet anoxic conditions. ISME J. 6, 847-862 (2011).

97. Caporaso, J. G. et al. QIIME allows analysis of high-throughput community sequencing data. Nat. Methods 7, 335-336 (2010).

98. Wang, Q. et al. Ecological patterns of nifH genes in four terrestrial climatic zones explored with targeted metagenomics using FrameBot, a new informatics tool. mBio 4, e00592-e613 (2013).

99. Kou, Y. et al. Scale-dependent key drivers controlling methane oxidation potential in Chinese grassland soils. Soil Biol. Biochem. 111, 104-114 (2017).

100. Kou, Y. et al. Climate and soil parameters are more important than denitrifier abundances in controlling potential denitrification rates in Chinese grassland soils. Sci. Total Environ. 669, 62-69 (2019).

101. Wei, H. et al. Contrasting soil bacterial community, diversity, and function in two forests in China. Front. Microbiol. 9, 1693 (2018).

102. Liu, W. et al. Critical transition of soil bacterial diversity and composition triggered by nitrogen enrichment. Ecology 101, e03053 (2020).

103. Tang, X., Liu, S., Zhou, G., Zhang, D. \& Zhou, C. Soil-atmospheric exchange of $\mathrm{CO}_{2}, \mathrm{CH}_{4}$, and $\mathrm{N}_{2} \mathrm{O}$ in three subtropical forest ecosystems in southern China. Glob. Change Biol. 12, 546-560 (2006).

\section{Acknowledgements}

This work was supported by the National Natural Science Foundation of China (Grant Numbers 31470529, 31270517) and the Natural Sciences and Engineering Research Council of Canada (NSERC) Discovery Grant.

\section{Author contributions}

C.P. and X.S. designed the experiment and supervised all work. Q.L. and J.Z. conducted the field and laboratory experiments. The manuscript was written by Q.L. and revised by Y.L.

\section{Competing interests}

The authors declare no competing interests.

\section{Additional information}

Supplementary Information The online version contains supplementary material available at https://doi. org/10.1038/s41598-021-84422-3.

Correspondence and requests for materials should be addressed to C.P. or X.S. 
Reprints and permissions information is available at www.nature.com/reprints.

Publisher's note Springer Nature remains neutral with regard to jurisdictional claims in published maps and institutional affiliations.

(c) (i) Open Access This article is licensed under a Creative Commons Attribution 4.0 International License, which permits use, sharing, adaptation, distribution and reproduction in any medium or format, as long as you give appropriate credit to the original author(s) and the source, provide a link to the Creative Commons licence, and indicate if changes were made. The images or other third party material in this article are included in the article's Creative Commons licence, unless indicated otherwise in a credit line to the material. If material is not included in the article's Creative Commons licence and your intended use is not permitted by statutory regulation or exceeds the permitted use, you will need to obtain permission directly from the copyright holder. To view a copy of this licence, visit http://creativecommons.org/licenses/by/4.0/.

(C) The Author(s) 2021 